\title{
Chemical composition, microbiological properties, and fatty acid profile of Italian-type salami with pork backfat substituted by emulsified canola oil
}

\author{
Angela Maria Backes ${ }^{1}$ Carlos Pasqualin Cavalheiro ${ }^{2}$ Flávia Santi Stefanello ${ }^{1}$ \\ Fernanda Luísa Lüdtke ${ }^{1}$ Nelcindo Nascimento Terra ${ }^{3}$ Leadir Lucy Martins Fries ${ }^{3 *}$
}

\begin{abstract}
${ }^{1}$ Programa de Pós-graduação em Ciência e Tecnologia dos Alimentos (PPGCTA), Centro de Ciências Rurais (CCR), Universidade Federal de Santa Maria (UFSM), Santa Maria, RS, Brasil.

${ }^{2}$ Escola de Medicina Veterinária e Zootecnia, Departamento de Medicina Veterinária Preventiva e Produção Animal, Universidade Federal da Bahia (UFBA), Salvador, BA, Brasil.

${ }^{3}$ Departamento de Tecnologia e Ciência dos Alimentos (DTCA), Centro de Ciências Rurais (CCR), Universidade Federal de Santa Maria (UFSM), 97105-900, Santa Maria, RS, Brasil. E-mail: lucymicro@yahoo.com.br. *Corresponding author.
\end{abstract}

\begin{abstract}
Vegetable oils have been used to substitute pork backfat to improve the fatty acid profile of fermented sausages. The aim of this study was to assess the chemical composition, microbiological properties, and fatty acid profile of Italian-type salami with pork backfat substituted (15\% and 30\%) by emulsified canola oil. Fat contents decreased while moisture contents increased in Italian-type salami with emulsified canola oil. The growth of lactic acid bacteria in salami was not affected by canola oil and absence of fecal coliforms, coagulase-positive staphylococci, and Salmonella were reported during processing offermented sausages. Lower levels of saturated fatty acids (SAFAs), higher levels of monounsaturated fatty acids (MUFAs) and polyunsaturated fatty acids (PUFAs) were observed in salami with emulsified canola oil. Together, our results indicated that substituting pork backfat with emulsified canola oil improved the nutritional values of Italian-type salami.

Key words: fermented sausages, vegetable oils, lipid content, polyunsaturated fatty acids, nutritional value.
\end{abstract}

Composição química, propriedades microbiológicas e perfil de ácidos graxos de Salame tipo Italiano com substituição da gordura animal por óleo de canola emulsionado

RESUMO: $O$ uso de óleos vegetais como substitutos da gordura animal em embutidos fermentados tem surgido como uma alternativa de produzir produtos cárneos com um melhor perfil lipídico. Assim, o objetivo deste trabalho foi avaliar a composição química, propriedades microbiológicas e o perfil de ácidos graxos de salame tipo Italiano elaborado com a substituição parcial da gordura suína (15 e 30\%) por emulsão com óleo de canola. A incorporação do óleo de canola reduziu o teor de gordura e aumentou o teor de umidade dos embutidos fermentados. Em relação às características microbiológicas, a adição de óleo de canola emulsionado não alterou o crescimento das bactérias láticas durante o processamento. Ainda, não foram detectadas contagens de coliformes fecais, staphylococci coagulase positiva e Salmonella. Em relação ao perfil de ácidos graxos, foi possível observar a redução nos teores totais de ácidos graxos saturados (SAFAs) e uma elevação nos valores de ácidos graxos monoinsaturados (MUFAs) e poliinsaturados (PUFAs) nos tratamentos adicionados de óleo de canola. Dessa forma, a substituição da gordura suína por óleo de canola emulsionado em salame tipo Italiano torna-se uma alternativa interessante na produção de produtos cárneos com melhores características nutricionais.

Palavras-chave: embutido curado fermentado, óleo vegetal, conteúdo lipídico, ácidos graxos polinsaturados, valor nutricional.

\section{INTRODUCTION}

Currently, the relation between fat intake and health is well known. Consumers are constantly seeking foods with a lower content of fat and cholesterol and with a favorable fatty acid profile (OSPINA et al., 2012). Although, meat and meat products are excellent sources of nutrients, they are rich in saturated fats and cholesterols and both are associated with higher risks of cancer, heart diseases, and obesity (ARIHARA, 2006). Therefore, reformulation is an approach to develop meat products with better nutritional values for consumers (SINGH et al., 2014).

The fatty acid profile of meat and meat products can be changed by supplementing animal feeds with monounsaturated fatty acids (MUFAs) and polyunsaturated fatty acids (PUFAs) or by adding different lipids into meat products during processing (ARIHARA, 2006; FRUET et al., 2016). Foods with higher amounts of MUFAs and PUFAs are recommended by health professionals because they are associated with lower risks of cancer of the breast, colon, coronary, and brain diseases (NETTLETON et al., 2016).

Vegetable oils including olive, canola, soybean, sunflower, and corn have been used to substitute animal fats in cooked (CHOI et al., 2010; YUNES et al., 2013; ASUMING-BEDIAKO et al., 2014), fresh (SELANI et al., 2016), and fermented meat products (PELSER et al., 2007; DEL NOBILE et al., 2009; MUGUERZA et al., 2011) to improve 
their nutritional values. Addition of emulsified canola oil in Italian-type salami did not affect its physicochemical characteristics $\left(\mathrm{pH}, \mathrm{a}_{\mathrm{w}}\right.$, weight loss, color and lipid oxidation) and sensory attributes (BACKES et al., 2013). Because of a favorable lipid profile [low SAFAs, high MUFAs and PUFAs, and rich in linolenic fatty acid $(\mathrm{C} 18: 3 \mathrm{n} 3)]$, canola oil is used to reformulate meat products replacing pork backfat (BAEK et al., 2016). Moreover, vegetable oils can improve the PUFA/SAFA ratio that is used to evaluate the nutritional quality of meat products.

The aim of this study was to evaluate the chemical composition, microbiological properties, and fatty acid profile of Italian-type salami with partial substitution of pork fat $(15 \%$ and $30 \%)$ by emulsified canola oil.

\section{MATERIALS AND METHODS}

To improve the stability of canola oil in fermented meat products, a soy protein isolate-stabilized oil/water emulsion was made. The emulsion was prepared as previously described by BLOUKAS et al. (1997). Briefly, four parts of water $\left(5^{\circ} \mathrm{C}\right)$ were mixed with one part of isolated soy protein (Bremil Food Industry, Arroio do Meio, Brazil) and followed by slow addition of six parts of canola oil (Bunge, São Paulo, Brazil). Formulation of fermented meat products consisted of $62.09 \%$ pork meat, $19.10 \%$ beef, 2.91\% salt (Synth, Diadema, Brazil), $0.28 \%$ glucose (Synth, Diadema, Brazil), 0.28\% sodium nitrite and nitrate (Bremil Food Industry, Arroio do Meio, Brazil), 0.23\% sodium ascorbate (Bremil Food Industry, Arroio do Meio, Brazil), 0.19\% sucrose (Synth, Diadema, Brazil), 0.19\% pepper (Kitano, São Paulo, Brazil), 0.19\% garlic powder (Knorr, São Paulo, Brazil), 0.19\% nutmeg (MasterFoods, São Paulo, Brazil), and $0.02 \%$ starter culture containing Pediococcus pentosaceus and Staphylococcus xylosus (Bactoferm SPX, Christian Hansen, Copenhagen, Denmark). Three different formulations were prepared: Control (C), 14.33\% pork backfat; Treatment 1 (T1), $12.18 \%$ pork backfat and $2.15 \%$ emulsified canola oil; and treatment 2 (T2), $10.03 \%$ pork backfat and $4.30 \%$ emulsified canola oil. The addition of emulsified canola oil in $\mathrm{T} 1$ and $\mathrm{T} 2$ corresponded to a reduction of $15 \%$ and $30 \%$ of pork backfat, respectively. These levels of replacement pork backfat by emulsified canola oil were chosen because are considered intermediated. In fermented meat sausages, it is notable the presence of pork backfat and higher levels of replacement may produce rejection by consumers. The ingredients were mixed in a mixing machine (in batches of $5 \mathrm{~kg}$ ) (Menoncin, Erechim, Brazil) and manually stuffed into artificial collagen casings $(60 \mathrm{~mm} \times 15 \mathrm{~cm})$ (Viscofan, Naturin, Weinheim, Germany). Sausages were then placed in a solution containing $20 \%$ potassium sorbate and allowed to ripen in a laboratory cabinet (Menoncin, Erechim, Brazil) for 28 days until water activity of 0.87 was attained. Temperature and relative humidity $(\mathrm{RH})$ were programmed as follows: day $1,25^{\circ} \mathrm{C} / 95 \%$; day 2 , $24^{\circ} \mathrm{C} / 93 \%$; day $3,23^{\circ} \mathrm{C} / 90 \%$; day $4,22^{\circ} \mathrm{C} / 85 \%$; day 5 , $21^{\circ} \mathrm{C} / 80 \%$; day $6,20^{\circ} \mathrm{C} / 75 \%$; and days $7-28,18^{\circ} \mathrm{C} / 75 \%$.

Moisture, fat, protein, and ash contents of salami were determined according to the AOAC (2005) methods. Moisture content was determined in an oven at $105^{\circ} \mathrm{C}$ until constant weight was attained. Total fat was extracted following the method as previously described by BLIGH \& DYER (1959). Protein content was measured using the Kjedahl method with digestion, distillation, and titration steps. Ash content was determined by heating at $500^{\circ} \mathrm{C}$.

Microbiological properties of the salami were evaluated on days $0,5,7,14,21$, and 28 . Overall, $25 \mathrm{~g}$ of samples were homogenized in $225 \mathrm{ml}$ of $0.1 \%$ peptone water (Oxoid Unipath Ltd., Basingstoke, Hampshire, UK), and serial dilutions were used for the microbiological analysis. Lactic acid bacteria (LAB), total coliforms, fecal coliforms, coagulase-positive staphylococci, and Salmonella were determined as described by DOWNES \& ITO (2000).

After extraction, total lipids were methylated using $12 \%$ boron trifluoride-methanol solution (w/w), as reported by JOSEPH \& ACKMAN (1992). Fatty acids methyl esters (FAMEs) were measured using a gas chromatograph (3300, Varian, Sunnyvale, USA) equipped with a flame ionization detector. Separation of FAMEs was performed on a Carbowax column $(30 \mathrm{~m} \times 0.25 \mathrm{~mm}$ ID $\times 0.25 \mu \mathrm{m}$ film thickness $)(\mathrm{J} \& \mathrm{~W}$ Scientific, Santa Clara, USA). During chromatographic analysis, oven temperature was raised from $140^{\circ} \mathrm{C}$ to $220^{\circ} \mathrm{C}$ at $2.5^{\circ} \mathrm{C} \mathrm{min}^{-1}$, and temperatures of the injector and detector were set at $230^{\circ} \mathrm{C}$ and $250^{\circ} \mathrm{C}$, respectively. Helium was used as a carrier gas with a flow rate of $1.6 \mathrm{~mL}$ $\mathrm{min}^{-1}$. Identification of FAMEs was by comparing their retention times with those in a mixed-standard (FAME mix, Supelco, USA). For each sample, relative FAMEs composition was quantified and data were presented as percentage weight for FAMEs composition.

A total of 18 sausages (three sausages for each batch $\mathrm{x}$ three batches $\mathrm{x}$ two replicates) were analyzed for different parameters. A completely randomized experimental design with three levels of emulsified canola oil $(0 \%, 15 \%$, and $30 \%$ ) was used. Analyses of variance were performed with a confidence interval of $95 \%$, followed by the posthoc Tukey test to establish statistical differences between treatments using SPSS 17.0 (SPSS, 2008). 


\section{RESULTS AND DISCUSSION}

Chemical compositions of the Italiantype salami are shown in table 1. Except for moisture content, both fat and protein contents in the salami were according to the limits established by Brazilian legislation (IN n $\left.{ }^{\circ} 22\right)$ (BRASIL, 2000). As canola oil was added in an emulsified form, significant increases $(P<0.05)$ in moisture contents were observed in both T1 and T2 compared with those in Control. Several studies have reported that the higher moisture content in meat products were due to decreased fat content and the presence of liquid fat in and on the surface of Italian-type salami made with emulsified canola oil (BLOUKAS et al., 1997; PELSER et al., 2007). In addition, higher moisture content reported in Italiantype salami made with emulsified canola oil could come from water added in the emulsion. UTRILLA et al. (2014) also related higher moisture content of dryripened venison sausages with higher proportion of olive oil throughout ripening time; although, differences were not particularly marked. In processing of dry-fermented meat sausages, $a_{w}$ is an important parameter once it sets water available for enzymatic and microbiological reactions. In salamis made with emulsified canola oil, BACKES et al. (2013) related $a_{w}$ values between 0.86 - 0.88 after 28 days of ripening. In our study, moisture values and $\mathrm{T} 1$ and $\mathrm{T} 2$ were $2 \%$ higher than those established by Brazilian legislation (BRASIL, 2000) and are not able to produce significant changes on final quality of salamis. In addition, according to RICKE \& KEETON (1997), meat products with moisture content up to $39 \%$ are considered shelf stable.

In contrast to moisture content, significant decreases $(P<0.05)$ in fat contents of the salami made with emulsified canola oil were observed compared with those in Control (Table 1). However, this effect was independent of the amount of emulsified canola oil added. Nevertheless, the fat content of Italian-type salami agrees with the Brazilian legislation, with the fat content set at a maximum of $32 \%$ (BRASIL, 2000). Protein contents were not significantly different between Control and T1 and T2. However, protein contents of our salami were similar to those of fermented meat sausages with canola oil, as reported by PELSER et al. (2007). The ash content of salami (T1) was significantly lower $(P<0.05)$ than that of salami (T2) and Control, and 7\% was acceptable for fermented meat products.

Microbiological properties of Italian-type salami are shown in figure 1 . LAB values increased from 6.00log colony-forming unit (CFU) $\mathrm{g}^{-1}$ at day 0 to $8.00 \log \mathrm{CFU} \mathrm{g}{ }^{-1}$ at day 5 during the fermentation process. The rapid growth of lactic acid bacteria (LAB) is desirable in fermented meat products, such as Italian-type salami, to prevent the growth of pathogenic bacteria (RACCACH, 1992). Growth of LAB was observed during the fermentation process and remained stable until the end of the process (day 28). LAB is the dominant group of microorganisms in fermented meat sausages, and they multiply to exceed $8 \log \mathrm{CFU} \mathrm{g}^{-1}$ at the end of the process (BENITO et al., 2007). The count of total coliforms decreased during fermentation. At day 28, total coliforms were not detected in salami (T1 and T2), and 1.10log CFU g ${ }^{-1}$ was reported in Control. Furthermore, fecal coliforms, coagulase-positive staphylococci, and Salmonella were not detected in Italian-type salami with emulsified canola oil. Brazilian legislation (RDC $\mathrm{n}^{\circ} 12$ ) establishes maximum counts of $3 \log \mathrm{CFU} \mathrm{g} \mathrm{g}^{-1}$ for fecal coliforms, 3.7log $\mathrm{CFU} \mathrm{\textrm {g } ^ { - 1 }}$ for coagulasepositive staphylococcus and absence of Salmonella in $25 \mathrm{~g}$ of sample (BRASIL, 2001). In addition, our microbiological results are in agreement with those reported by BLOUKAS et al. (1997), MUGUERZA et al. (2001), and DEL NOBILE et al. (2009).

The fatty acid profile, SAFAs, MUFAs, PUFAs, and PUFA/SAFA ratio of Italian-type salami are shown in table 2. Canola oil mostly consists of

Table 1 - Effects of substituting pork backfat with emulsified canola oil on the chemical composition of Italian-type salami (expressed in $\left.\mathrm{g} 100 \mathrm{~g}^{-1}\right)$.

\begin{tabular}{|c|c|c|c|c|}
\hline \multirow[b]{3}{*}{ Moisture } & \multicolumn{3}{|c|}{-----------------------------------------------Treatments------------------------------------------- } & \multirow[t]{2}{*}{ Legislation ${ }^{*}$} \\
\hline & C & $\mathrm{T} 1$ & $\mathrm{~T} 2$ & \\
\hline & $34.56 \pm 0.62^{b}$ & $36.94 \pm 0.58^{\mathrm{a}}$ & $37.03 \pm 0.23^{\mathrm{a}}$ & Max. 35.00 \\
\hline Fat & $28.48 \pm 0.51^{b}$ & $24.06 \pm 0.81^{\mathrm{a}}$ & $25.54 \pm 0.82^{\mathrm{a}}$ & Max. 32.00 \\
\hline Protein & $28.36 \pm 0.42$ & $28.06 \pm 0.56$ & $28.87 \pm 0.72$ & Min. 25.00 \\
\hline Ash & $7.42 \pm 0.10^{\mathrm{a}}$ & $7.17 \pm 0.06^{b}$ & $7.50 \pm 0.08^{a}$ & - \\
\hline
\end{tabular}

${ }^{\mathrm{a}-\mathrm{b}}$ Mean values in the same row not followed by a common letter differ significantly $(P<0.05)$;

C: no pork backfat replacement; T1 and T2: $15 \%$ and $30 \%$ of pork backfat substituted with emulsified canola oil, respectively;

${ }^{*}$ Values according to Brazilian legislation (BRASIL, 2000). 


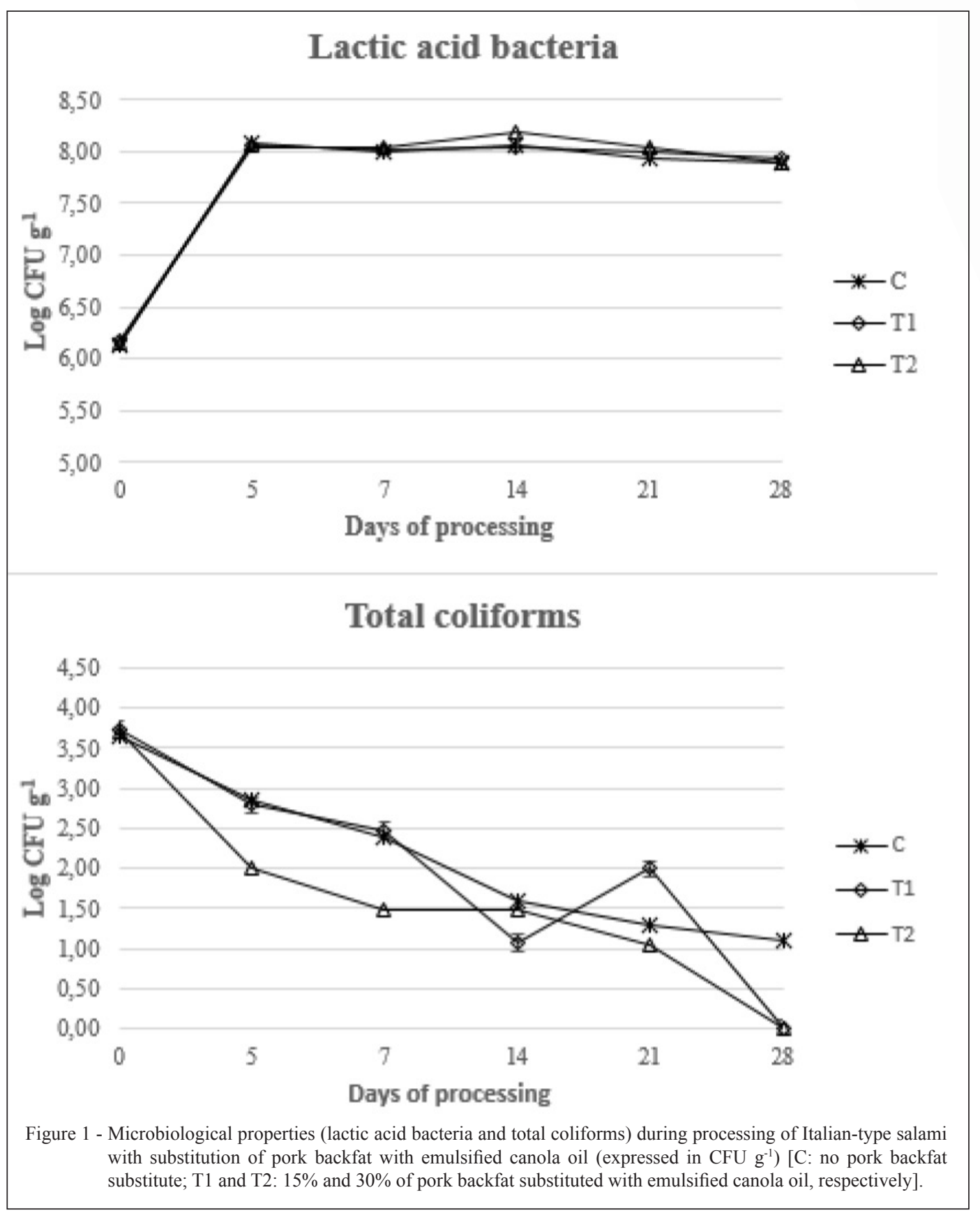

MUFA (oleic, C18:1n9) and PUFA (linoleic, C18:2n6) and a small amount of SAFAs, mainly consisting of palmitic (C16:0) and stearic (C18:0) acids. O'BRIEN (2008) reported that canola oil consisted of half the amount of SAFAs compared with soybean and corn oils, but it is rich in unsaturated fatty acids.

With respect to the fatty acid profile, significant reductions $(P<0.05)$ in myristic $(\mathrm{C} 14: 0)$, palmitic (C16:0), stearic (C18:0), and arachidic
(C20:0) fatty acids were observed in salami with canola oil (T1 and T2) compared with those in Control (Table 2). However, a significant reduction $(P<0.05)$ in saturated margaric (C17:0) acid was observed only with $30 \%$ substitution. Significant reductions of SAFAs levels, including C14:0 and C16:0, improved the nutritional value of our salami, and this was attributable to the lipid profile of canola oil. Similar findings in frankfurter sausages and hamburger with 
Table 2 - Fatty acid content (expressed in \% of total fatty acids methyl esters), saturated fatty acids (SAFAs), monounsaturated fatty acids (MUFAs), polyunsaturated fatty acids (PUFAs), PUFA/SAFA and n6/n3 ratios in Italian-type salami with pork backfat substituted by emulsified canola oil.

\begin{tabular}{|c|c|c|c|c|}
\hline & $\mathrm{C}$ & $\mathrm{T} 1$ & $\mathrm{~T} 2$ & Canola oil \\
\hline C14:0 & $0.97 \pm 0.08^{\mathrm{a}}$ & $0.73 \pm 0.06^{\mathrm{b}}$ & $0.79 \pm 0.05^{\mathrm{b}}$ & $0.05 \pm 0.02$ \\
\hline C16:0 & $27.27 \pm 0.40^{\mathrm{a}}$ & $19.71 \pm 0.74^{\mathrm{b}}$ & $19.86 \pm 0.42^{\mathrm{b}}$ & $3.80 \pm 0.43$ \\
\hline C17:0 & $0.60 \pm 0.03^{\mathrm{a}}$ & $0.53 \pm 0.03^{\mathrm{ab}}$ & $0.47 \pm 0.02^{\mathrm{b}}$ & ND \\
\hline C18:0 & $13.95 \pm 0.25^{\mathrm{a}}$ & $10.79 \pm 0.27^{b}$ & $9.87 \pm 0.45^{\mathrm{c}}$ & $1.80 \pm 0.22$ \\
\hline $\mathrm{C} 20: 0$ & $0.74 \pm 0.07^{\mathrm{a}}$ & $0.17 \pm 0.01^{\mathrm{b}}$ & $0.20 \pm 0.01^{\mathrm{b}}$ & $0.43 \pm 0.09$ \\
\hline $\mathrm{C} 16: \ln 7$ & $1.58 \pm 0.03$ & $1.36 \pm 0.07$ & $1.42 \pm 0.05$ & $0.16 \pm 0.03$ \\
\hline $\mathrm{C} 17: \ln 7$ & $0.41 \pm 0.01^{\mathrm{a}}$ & $0.44 \pm 0.03^{\mathrm{a}}$ & $0.38 \pm 0.00^{\mathrm{b}}$ & ND \\
\hline $\mathrm{C} 18: \ln 9$ & $47.48 \pm 0.50^{b}$ & $49.69 \pm 1.22^{\mathrm{a}}$ & $49.12 \pm 0.92^{\mathrm{a}}$ & $51.41 \pm 1.13$ \\
\hline $\mathrm{C} 20: \ln 9$ & $0.15 \pm 0.05^{b}$ & $0.71 \pm 0.05^{\mathrm{a}}$ & $0.65 \pm 0.06^{\mathrm{a}}$ & $0.67 \pm 0.34$ \\
\hline $\mathrm{C} 18: 2 \mathrm{n} 6$ & $2.62 \pm 0.29^{b}$ & $11.06 \pm 0.43^{\mathrm{a}}$ & $11.98 \pm 0.95^{\mathrm{a}}$ & $32.91 \pm 0.20$ \\
\hline $\mathrm{C} 18: 3 \mathrm{n} 3$ & $0.12 \pm 0.02^{\mathrm{c}}$ & $0.39 \pm 0.04^{\mathrm{b}}$ & $0.59 \pm 0.07^{\mathrm{a}}$ & $4.69 \pm 0.27$ \\
\hline $\mathrm{C} 20: 2 \mathrm{n} 6$ & $0.08 \pm 0.03$ & $0.08 \pm 0.06$ & $0.05 \pm 0.04$ & $0.34 \pm 0.06$ \\
\hline$\sum$ SAFAs & $43.53^{\mathrm{a}}$ & $31.93^{\mathrm{b}}$ & $31.19^{\mathrm{b}}$ & 6.08 \\
\hline$\sum$ MUFAs & $49.62^{b}$ & $52.20^{\mathrm{a}}$ & $51.57^{\mathrm{a}}$ & 52.24 \\
\hline$\sum$ PUFAs & $2.82^{\mathrm{b}}$ & $11.53^{\mathrm{a}}$ & $12.62^{\mathrm{a}}$ & 37.94 \\
\hline PUFA/SAFA & $0.06^{\mathrm{b}}$ & $0.36^{\mathrm{a}}$ & $0.40^{\mathrm{a}}$ & 6.24 \\
\hline n6/n3 & $22.50^{\mathrm{b}}$ & $28.56^{\mathrm{a}}$ & $20.38^{\mathrm{c}}$ & 7.08 \\
\hline
\end{tabular}

${ }^{\mathrm{a}-\mathrm{c}}$ Mean values in the same row not followed by a common letter differ significantly $(P<0.05)$;

C: no pork backfat substitute; T1 and T2: $15 \%$ and $30 \%$ of pork backfat substituted with emulsified canola oil, respectively. ND: Not detected.

canola oil addition have been reported (CHOI et al., 2010; SELANI et al., 2016).

Although canola oil contained high levels of MUFAs, only gadoleic (C20:1n9) fatty acid was significantly increased in salami made with emulsified canola oil compared with that in Control (Table 2). However, MUFAs levels were significantly increased in salami with canola oil. Other studies have reported increases in MUFAs contents in fermented meat products with pork backfat substituted with olive oil (MUGUERZA et al., 2001; DEL NOBILE et al., 2009). In contrast, PELSER et al. (2007) reported a reduction in MUFAs contents in fermented meat sausages with linseed oil but an increase when canola oil was used.

As shown in table 2, PUFAs, linoleic (C18:2n6), and linolenic (C18:3n3) fatty acids were significantly increased in salami with emulsified canola oil compared with those in Control. In addition, the increase in $\mathrm{C} 18: 3 \mathrm{n} 3$ fatty acid was reflected by the amount of canola oil added. However, the low level of eicosadienoic (C20:2n6) fatty acid in canola oil did not change its level in the salami. Variations in the fatty acid profiles of Italian-type salami with emulsified canola oil are in agreement with other meat products containing vegetable oils (PELSER et al., 2007; CHOI et al., 2010; ASUMING-BEDIAKO et al., 2014; BAEK et al., 2016; SELANI et al., 2016). Substituting pork backfat with emulsified canola oil significantly reduced $(P<0.05)$ SAFAs levels and increased $(P<0.05)$ MUFAs and PUFAs levels in salami (T1 and T2) compared with those in Control. According to LI et al. (2015), PUFAs reduced cholesterol levels in the blood plasma and thus lowers blood pressure and prevents cardiac arrhythmias. The PUFA/SAFA ratio is one of the parameters currently used to assess the food nutritional quality with respect to lipid content (ANSORENA \& ASTIASARÁN, 2004). The ratio should be higher than 0.4 to reduce the negative effects of SAFAs on plasma low-density lipoprotein (LDL) cholesterol levels (ENSER et al., 2000). As shown in table 2, significant increases in PUFA/SAFA ratios are observed in salami with canola oil (T1 and T2) compared with those in Control. High n6/n3 ratios are associated with some health problems, including cardiovascular and inflammatory diseases. In counterpart, low n6/n3 ratios may exert suppressive effects (SIMOPOULOS, 2002). According to SALCEDO-SANDOVAL et al. (2014), for prevention of cardiovascular disease, the recommendation is to reduce the value to less than 4 . However, some meats naturally have the $n 6 / \mathrm{n} 3$ ratio 
higher than this value (WOOD et al., 2004). According to table 2, the replacement of pork backfat by emulsified canola oil (T2) was not enough to reduce $\mathrm{n} 6 / \mathrm{n} 3$ ratio of meats to the recommended level, but the incorporation of $30 \%$ of emulsified canola oil (T2) was able $(\mathrm{P}<0.05)$ to reduce the ratio when compared to control (C) treatment. Therefore, substitution of pork backfat with emulsified canola oil improves the nutritional quality of Italian-type salami.

\section{CONCLUSION}

Substituting $15 \%$ and $30 \%$ of pork backfat with emulsified canola oil decreased the fat content and increased the moisture content of Italian-type salami. With the exception of moisture content, fat and protein contents were in agreement with Brazilian legislation. Addition of emulsified canola oil in Italian-type salami did not affect the expected growth of $\mathrm{LAB}$, and pathogenic bacteria such as fecal coliforms, coagulase-positive staphylococci, and Salmonella were not detected during fermentation. Moreover, emulsified canola oil improves the fatty acid profile of Italian-type salami by decreasing SAFAs contents and increasing MUFAs and PUFAs contents; thus, canola oil increases the PUFA/SAFA ratio.

Our results showed that partial substitution of animal fat with emulsified canola oil could be used to diversify meat products and improve the fatty acid profiles of Italian-type salami. In addition, our methodology can be applied to other vegetable oils such as flaxseed, corn, and sunflower in various meat products.

\section{REFERENCES}

ANSORENA, D.; ASTIASARÁN, I. The use of linseed oil improves nutritional quality of the lipid fraction of dry-fermented sausages. Food Chemistry, v.87, n.1, p.69-74, 2004. Available from: <http:// www.sciencedirect.com/science/article/pii/S0308814603005685>. Accessed: Jan. 05, 2016. doi: 10.1016/j.foodchem.2003.10.019.

AOAC (ASSOCIATION OF OFFICIAL ANALYTICAL CHEMISTRY). Official methods of analysis. 18.ed. Maryland, 2005.

ARIHARA, K. Strategies for designing novel functional meat products. Meat Science, v.74, n.1, p.219-229, 2006. Available from: < http:// www.sciencedirect.com/science/article/pii/S0309174006001446>. Accessed: Jan. 14, 2016. doi: 10.1016/j.meatsci.2006.04.028.

ASUMING-BEDIAKO, N. et al. Effects of replacing pork backfat with emulsified vegetable oil on fatty acid composition and quality of UK-style sausages. Meat Science, v.96, n.1, p.187-194, 2014. Available from: $<$ http://www.sciencedirect.com/science/article/pii/ S0309174013003082>. Accessed: Mar. 15, 2015. doi: 10.1016/j. meatsci.2013.06.031.

BACKES, A.M. et al. Physico-chemical characteristics and sensory acceptance of Italian-type salami with canola oil addition. Semina: Ciências Agrárias, v.34, n.6, p.3709-3720,
2013. Available from: <http://www.uel.br/revistas/uel/index.php/ semagrarias/article/view/15141>. Accessed: Mar. 19, 2017. doi: 10.5433/1679-0359.2013v34n6Sup12p370.

BAEK, K.H. et al. Effects of replacing pork back fat with canola and flaxseed oils on physicochemical properties of emulsion sausages from spent layer meat. Asian-Australasian Journal of Animal Sciences, v.29, n.6, p.865-871, 2016. Available from: $<$ http://ajas.info/journal/view.php?doi=10.5713/ajas.15.1050>. Accessed: Apr. 28, 2016. doi. 10.5713/ajas.15.1050.

BLIGH, E.G.; DYER, W.J. A rapid method of total lipid extraction and purification. Canadian Journal of Biochemistry and Physiology, v.37, n.8, p.911-917, 1959. Available from: <http:// www.nrcresearchpress.com/doi/abs/10.1139/o59-099>. Accessed: Nov. 28, 2015. doi: 10.1139/o59-099.

BLOUKAS, J.G. et al. Effect of replacing pork backfat with olive oil on processing and quality characteristics of fermented sausages. Meat Science, v.45, n.2, p.133-144, 1997. Available from: <http:// www.sciencedirect.com/science/article/pii/S0309174096001131>. Accessed: Feb. 03, 2016. doi: 10.1016/S0309-1740(96)00113-1.

BRASIL. Ministério da Agricultura, Pecuária e do Abastecimento. Secretaria de Defesa Agropecuária. Instrução Normativa nº. 22, de 31 de julho de 2000, Regulamentos Técnicos de Identidade e Qualidade de Salame Tipo Italiano. Diário Oficial [da] República Federativa do Brasil, Brasília, Ago. 03, 2000. Seção I, p.15-28.

BRASIL. Agência Nacional de Vigilância Sanitária. Resolução RDC nº. 12, de 02 de janeiro de 2001, Regulamento Técnico Sobre Padrões Microbiológicos para Alimentos. Diário Oficial [da] República Federativa do Brasil, Brasília, Jan. 02, 2001.

CHOI, Y.S. et al. Effects of replacing pork fat with vegetable oils and rice bran fiber on the quality of reduced-fat frankfurters. Meat Science, v.84, n.3, p.557-563, 2010. Available from: $<$ http:// www.sciencedirect.com/science/article/pii/S0309174009003325>. Accessed: Oct. 14, 2015. doi: 10.1016/j.meatsci.2009.10.012.

DEL NOBILE, M.A. et al. New strategies for reducing the pork back-fat content in typical Italian salami. Meat Science, v.81, n.1, p.263-269, 2009. Available from: <http://www.sciencedirect. com/science/article/pii/S0309174008002544> . Accessed: Mar. 14, 2016. doi: 10.1016/j.meatsci.2008.07.026.

DOWNES, F.P.; ITO, H. Compendium of methods for the microbiological examination of foods. 4.ed. Washington: American Public Health Association. 2001. 676p.

ENSER, M. et al. Feeding linseed to increase the n-3 PUFA of pork: fatty acid composition of muscle, adipose tissue, liver and sausages. Meat Science, v.55, n.2, p.201-212, 2000. Available from: <http:// www.sciencedirect.com/science/article/pii/S0309174099001448>. Accessed: Mar. 14, 2016. doi: 10.1016/S0309-1740(99)00144-8.

FRUET, A.P.B. et al. Whole grains in the finishing of culled ewes in pasture or feedlot: Performance, carcass characteristics and meat quality. Meat Science, v.113, n.14, p.97-103, 2016. Available from: <http:/ www.sciencedirect.com/science/article/pii/S0309174015301339>. Accessed: June 15, 2016. doi: 10.1016/j.meatsci.2015.11.018.

JOSEPH, J.D.; ACKMAN, R.G. Capillary column gas chromatographic method for analysis of encapsulated fish oils and fish oil ethyl esters: collaborative study. Journal of AOAC International, v.75, n.3, p.488-506, 1992. 
LI, Y. et al. Saturated fats compared with unsaturated fats and sources of carbohydrates in relation to risk of coronary heart disease: a prospective cohort study. Journal of the American College of Cardiology, v.66, n.14, p.1538-1548, 2015. Available from: <http:// www.sciencedirect.com/science/article/pii/S0735109715046914>. Accessed: Dec. 03, 2015. doi: 10.1016/j.jacc.2015.07.055.

MUGUERZA, E. et al. Effects of replacing pork backfat with pre-emulsified olive oil on lipid fraction and sensory quality of Chorizo de Pamplona - a traditional Spanish fermented sausage. Meat Science, v.59, n.3, p.251-258, 2001. Available from: <http:// www.sciencedirect.com/science/article/pii/S0309174001000754>. Accessed: Mar. 01, 2016. doi: 10.1016/S0309-1740(01)00075-4.

NETTLETON, J.A. et al. Dietary fatty acids: Is it time to change the recommendations? Annals Nutrition \& Metabolism, v.68, n.4, p.249-257, 2016. Available from: <http://www.karger.com/Article/ FullText/446865>. Accessed: May 04, 2016. doi: 10.1159/000446865.

O'BRIEN, R.D. Fats and oils: formulating and processing for applications. 3.ed. Lancaster: Technomic Publishing Company, 2008. 680p.

OSPINA, E.J.C. et al. Substitution of saturated fat in processed meat products: a review. Critical Reviews in Food Science and Nutrition, v.52, n.2, p.113-122, 2012. Available from: <http://www. tandfonline.com/doi/abs/10.1080/10408398.2010.493978?journa 1Code=bfsn20\#.V2bHJGgrLIU>. Accessed: Sept. 15, 2015. doi: 10.1080/10408398.2010.493978.

PELSER, W.M. et al. Lipid oxidation in n-3 fatty acid enriched Dutch style fermented sausages. Meat Science, v.75, n.1, p.1-11, 2007. Available from: <http://www.sciencedirect.com/science/ article/pii/S0309174006001999>. Accessed: Jan. 13, 2016. doi: 10.1016/j.meatsci.2006.06.007.

RICKE, S.C.; KEETON, J.T. Fermented meat, poultry, and fish products. In: DOYLE, M.P. et al. Food microbiology: fundamental and frontiers. Washington, DC, USA: ASM, 1997. P.610-628.

SALCEDO-SANDOVAL, L. et al. Effect of cooking method on the fatty acid content of reduced-fat and PUFA-enriched pork patties formulated with a konjac-based oil bulking system. Meat Science, v.98, n.4, p.795-803, 2014. Available from: $<\mathrm{http}: / /$ www.sciencedirect.
com/science/article/pii/S0309174014002654>. Accessed: Mar. 08, 2017. doi: 10.1016/j.meatsci.2014.07.034.

SELANI, M.M. et al. Pineapple by-product and canola oil as partial fat replacers in low-fat beef burger: effects on oxidative stability, cholesterol content and fatty acid profile. Meat Science, v.115, n.1, p.9-15, 2016. Available from: <http://www.sciencedirect.com/ science/article/pii/S030917401630002X>. Accessed: Mar. 15, 2016. doi: 10.1016/j.meatsci.2016.01.002.

SIMOPOULOS, A.P. The importance of the ratio of ômega-6/ômega-3 essential fatty acids. Biomedicine \& Pharmacotherapy, v.58, n.8, p.365-379, 2002. Available from: <http://www.sciencedirect.com/ science/article/pii/S0753332202002536>. Accessed: Mar. 11, 2017. doi: 10.1016/S0753-3322(02)00253-6.

SINGH, R. et al. Quality of $\omega-3$ fatty acid enriched low-fat chicken meat patties incorporated with selected levels of linseed flour/oil and canola flour/oil. Journal of Food Science and Technology, v.51, n.2, p.353-358, 2014. Available from: <http://link.springer. com/article/10.1007\%2Fs13197-011-0507-9>. Accessed: Dec. 15, 2015. doi:10.1007/s13197-011-0507-9.

SPSS, IBM. SPSS $\mathbf{1 7 . 0}$ for Windows. Armonk: IBM Corporation, 2008

UTRILLA, M.C. et al. Effect of partial replacement of pork meat with na oilive oil organogel on the physicochemical and sensory quality of dry-ripened venison sausages. Meat Science, v.97, p.575-582, 2014. Available from: $<$ http://www.sciencedirect.com/science/article/ pii/S0309174014000631>. Accessed: Mar. 25, 2017. doi: 10.1016/j. meatsci.2014.03.001.

WOOD, J.D. et al. Effects of fatty acids on meat quality: a review. Meat Science, v.66, n.1, p.21-32, 2004. Available from: <http:// www.sciencedirect.com/science/article/pii/S0309174003000226>. Accessed: Mar. 11, 2017. doi: 10.1016/S0309-1740(03)00022-6.

YUNES, J.F.F. et al. Fatty acid profile and cholesterol content of mortadella prepared with vegetable oils. Ciência Rural, v.43, n.5, p.924-929, 2013. Available from: $<$ http://www.scielo.br/scielo.php?script=sci arttext\&pid $=$ S0103-84782013000500028 $>$. Accessed: July 15, 2016. doi: 10.1590/ S0103-84782013005000038. 